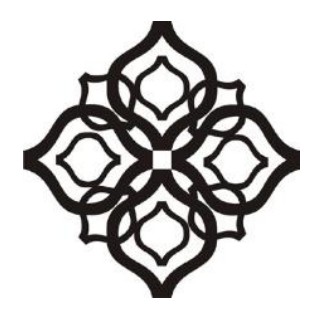

Shirkah

Journal of Economics and Business 
Shirkah: Journal of Economics and Business

Volume 5, No. 3, September-December 2020

ISSN: 2503-4235 (p); 2503-4243 (e)

\section{Table of Contents}

Institutional Quality and Sukuk Development: A Study of Five 286 OIC Countries

Nuhbatul Basyariah, Hadri Kusuma, Ibnu Qizam

Performance of GoFood MSEs Partnership: An Integration of

Entrepreneurial Orientation, Marketing Capabilities, and

Brand Orientation

Septi Kurnia Prastiwi, Asep Maulana Rohimat

Islamic Social Reporting Disclosure of Sharia Commercial

Banks in Indonesia: A Form of Social Responsibility

Riduwan, Lu'liyatul Mutmainah, Rofiul Wahyudi

Concentration and Specialization of Economic Activities in the 362

Kingdom of Saudi Arabia

Salim Bourchid Abdelkader, Hamidouche M'hamed, Abderrazak

Ahmed Zian

Indonesian Islamic Commercial Banks' Efficiency: A Stochastic 386 Frontier Analysis

Sylva Alif Rusmita, Devy Ariesta Putri

Islamic Economics Development in Indonesia: Reflection on

Contemporary Thoughts of Muslim Intellectuals

Zainal Abidin 


\title{
Islamic Economics Development in Indonesia: Reflection on Contemporary Thoughts of Muslim Intellectuals
}

\author{
Zainal Abidin \\ Faculty of Islamic Economics and Business, IAIN Madura, Indonesia \\ zain@iainmadura.ac.id
}

\begin{abstract}
This study aims to establish the record of accomplishment of the strong hallmark of Islamic economic thought and its contribution to economic development. The ideas rooted from the Muslim intellectuals in Indonesia, the scholars of the State Islamic Religious Colleges (PTKIN) as institutions mandated in developing Islamic economics and human resources, were discussed to outline the multifaceted phenomenon of Islamic economic development. This study scrutinizes ideas conveyed in internationally reputed, Sinta 1-indexed, Web of Science-indexed, or Scopus-indexed journals. This study outlined a qualitative approach in the form of library research using content analysis. This study disclosed that Indonesian Muslim intellectuals brought to light the issue of zakah excessing other themes in the Islamic economy as the solution to perennial problems of the social, political, and cultural conditions of Indonesian society. The results of this study contribute to the views of Islamic economic concept and practice as insights and references of its continuous development in Indonesia.
\end{abstract}

Keywords: Islamic Economic Thoughts; Islamic Economics Development; Contemporary Muslim Intellectuals 


\section{Introduction}

State Islamic Religious College in Indonesia (henceforth PTKIN) is expected to assume broader roles compared to universities in terms of Islamic economic movement. It is the PTKIN's critical mandate to yield qualified human resources in the Islamic economic field. Indeed, PTKIN has been known to be moderate and liberal with respect to the appearance and style of thinking, likewise in the field of Islamic economics. Hence, people involving in PTKIN have a crucial role and responsibility to ensure critical ideas of Islamic economic development in Indonesia.

To this day, Islamic economics is simply considered as a discourse or symbol. There are also claims that Islamic financial institutions allegedly are just agents of conventional financial institutions and Islamic financial institutions do not distinct largely from the conventional ones. This assertion was essentially taken after the idea of Prawiranegara and Partadiredja (in Rahardjo, 1985) who put forward the thought by bringing up that economic activities focusing on Islamic teachings (the substance) called the Islamic economic system. This view, in any case, is not in line with the standpoint enunciated by Rahardjo (1985) that the Islamic economic system holds its own concept and theories that are disparate from the concept of capitalist and socialist economics. This is thereby in accordance with his statement that the Islamic economic system is a concept and theory established on the basis of Islamic teachings (Rahardjo, 1985).

In addressing whether Islamic economics is just labelling of conventional economics, Syahbudi (2003) proffered distinct views. Syahbudi (2003) asserted the emergence of Islamic economics as an alternative to occupying the vacuum of economic capitalism and socialism. The labeling is only a matter of name, yet the most substantial thing is how Islamic fervor imbues this alternative. Quoting from Hasanuzzaman, Syahbudi (2003) defines Islamic economics as the erudition and application of commandments and procedures 
established by sharia law which avert injustice in extracting and exerting material resources to cater to human needs that enable them to perform their obligations to Allah and society.

Sudiarti et al (2017) further added that the merging of Islam and the economy is to yield benefits for Muslims, divinity as the core of all values of Islamic economic system, wherein all economic activities is subject to this value. This corroborates with Chapara (1997) that Islamic economics can be regarded as divine economics. Chapara (1997) emphasized that all aspects within the systems as well as economic actors must adhere to the faith that all economic factors including human beings, basically belong to Allah, and to Him (to His rules) return all the matters.

Afterwards the polemic on the discourse of Islam and economics bring a definition of what Islamic economics is. Manan (1970) defines Islamic economics as a social science that delves on economic problems imbued with Islamic values. Meanwhile, Indriati and Nugroho (2019) defines Islamic economics as a system that seeks to discern economics and the problems of human life from an Islamic perspective. Ulum (2008) proposed the definition of Islamic economics as the erudition and application of teachings and precepts contained in Islamic law to prevent injustice in attaining material resources so that human satisfaction is created to enable them to carry out Allah's orders. Siddqi (1986) defines Islamic economics as the answer to Islamic Philosophers for the challenges encountered in their time with al-Qur'an, al-Sunnah thinking, and experience as guidelines. Rahardjo (1985) classifies Islamic economics as economics built upon Islamic values and teachings, a system, and the economy of Muslims. Subsequently, Adibuddin et al. (2019) goes into detail that Islamic economics is the science that delves into the behavior of Muslims in an Islamic society that adheres to the al-Qur'an, hadits, qiyas, and Ijma'.

Aside from the polemic regarding the meaning of Islamic economics, basically, Islamic economics started from a construct or thought initiated by previous economic scholars. Regarding discourse 


\section{Zainal Abidin}

and thoughts on Islamic economics development, Jahar (2015) illustrates that the Islamic economics thought movement in Indonesia occurred from the post-independence era to reformation. As of now, Islamic economic activities emphasized entrepreneurship for community development as a response to the capitalism that was considered not to provide improvements to society's social and economic. Several Islamic banks and Islamic financial institutions were established as the solution to community development. This thought underwent a shift in meaning when Indonesia rode into a period of democracy that emphasized transparency and accountability. Nowadays, economic thought is directed to community empowerment that is more public and welfare in nature. This response is manifested in the inception of Zakah Law, Waqf Law, etc. This is where a shift in meaning from merely symbolical to substantial occurs.

The battle of ideas regarding Islamic economics and its problems are listed in scientific journals. Moreover, with the ranking system in the form of Sinta (Science and Technology Index) launched by the Ministry of Research, Technology and Higher Education of the Republic of Indonesia, it shall decree the position of a journal. It is convenient to record traces of contemporary Indonesian Muslim intellectuals' thoughts. The Muslim intellectuals' thoughts in the realm of Islamic economics can be understood to map how they contribute to the flourish of Indonesian Islamic economics.

Given the above-mentioned contextual issue, this study intends to gauge the following research questions: (1) how is the contribution of economists' thoughts from Muslim intellectuals of PTKIN? (2) what is the impact of economic thought in responding to the problems of Islamic economics in Indonesia? (3) what discourses were born from the thoughts of PTKIN economists? (4) how is the actual track record of Muslim intellectuals thought in the realm of Islamic economics? (5) how do they contribute to the growth of the Indonesian Islamic economy?. Specifically, the latter two issues are discussed in the present study since both are considered relevant to the progress of 
Islamic economics discourse in Indonesia today. The present study is novel as despite the interest, no one to the best of the author's knowledge attempts to examine diverse thoughts of contemporary Muslim intellectuals in Indonesia that are found in journals of Islamic Studies in Indonesia with international reputation indexed by Scopus, Sinta 1 , and Web of Science.

\section{Review of Literature}

The scholars' debate in discerning the concept of Islamic economics itself defines Islamic economics as the economy of Muslims, Islamic economics as economics inspired by Islam itself, or the map of Islamic economics thought from classical to this contemporary. Basically, Islamic economics thought has been born since the time of Prophet Muhammad spreading Islam. Nonetheless, Islamic thought had not been modified as it is today. The development of economics during the Umayyad and Abbasids dynasty was not documented in the narratives of scholars' thought. Around then, economics was still amalgamated with political, social, and sociological science. Accordingly, Islamic Philosophers were acknowledged as economists since they have written works to be accessed by later generations. Every Islamic Philosopher who has contributed to economic thought was influenced by his life background, milieu, country state, etc. (Ulum, 2008).

Over time, Islamic economic growth has progressed from the initial period which was merely a fragment of figh and developed into a concept of thought. Shidqi (1986) classifies the periodization of classical Islamic economic thought and civilization into the basic phases of Islamic economics into three phases: the basic phase, the phase of progress, and the phase of stagnation. First, the initial phase is the basic principles of Islamic economics that started from the early of hijra until the fifth year of hijra. Islamic economic thought was born from the specialists of Figh and Sufism and philosophers. Their thoughts have their respective focus corresponding to their scientific 


\section{Zainal Abidin}

background. An expert in figh (fuqahā) paid attention to maslahah (something permitted) and mafsadat (something forbidden). This thought is positive, normative in nature, and more microeconomic. The Sufism expert holds a focus on circumstances to correspond to mutually beneficial partnerships that is not voracious in taking advantage of the avenues given by Allah (Subhanahu Wa Ta'ala) and refuse exorbitant demands for opulence. This thought is normative with a positive outlook and more microeconomic. Philosophers' focus of thought is on the concept of happiness ( $\left.s a^{\prime} a d a h\right)$. Its approach is global and rational and the methodology is loaded with positive economic analysis and more macroeconomic. The well-known Islamic scholars at this time include Abu Hanifah (A.H. 150) who offered a concept of salam buying and defending the economy of the weak, Abu Yusuf (A.H. 182) who held thoughts on public finances and price control, As Syaibani (A.H. 182) whose thoughts corresponded to producers, consumers, and distribution of commodity and Ib Miskawaih (A.H. 442) who focused on the thought of the financial system.

Second, the subsequent phase is the upturn happening from A.D. 11 to 15 , the time Islam set foot in the golden age of science including the realm of Islamic economics. At this time, the Islamic dominion stretched from the West to the East becoming scientific study centers that gave birth to several Muslim intellectuals such as Al-Ghazali (A.H. 505A.D. 1111), Ibnu Taimiyah (A.H. 728/A.D. 1328), Ibnu Khaldun (A.H 808/A.D. 1406), and Al-Maqrizi (A.H 845/A.D. 1441). Al Ghazali was more focused on consumer behavior, market evolution, and the concept of finances and revenue. Meanwhile, Ibnu Taimiyah focused on the concept of price, the role of hisbah, state finances, and the concept of money. Meanwhile, Ibnu Khaldun focused more on public finance, the concept of price, the concept of money, and the theory of production. Furthermore, Al Maqrizi focused more on the concept of money and production theory.

Third, the period where the gate of Ijtihad was closed between 1446 A.D. and 1932 A.D. At this time, the fiqh experts no longer put 
forth fatwa but merely re-elaborated fatwa of previous scholars. They are Syah Waliyullah al-Dihlawi, Muhammad Abduh, Jalaluddin alAfghani, and Muhammad Iqbal as some scholars.

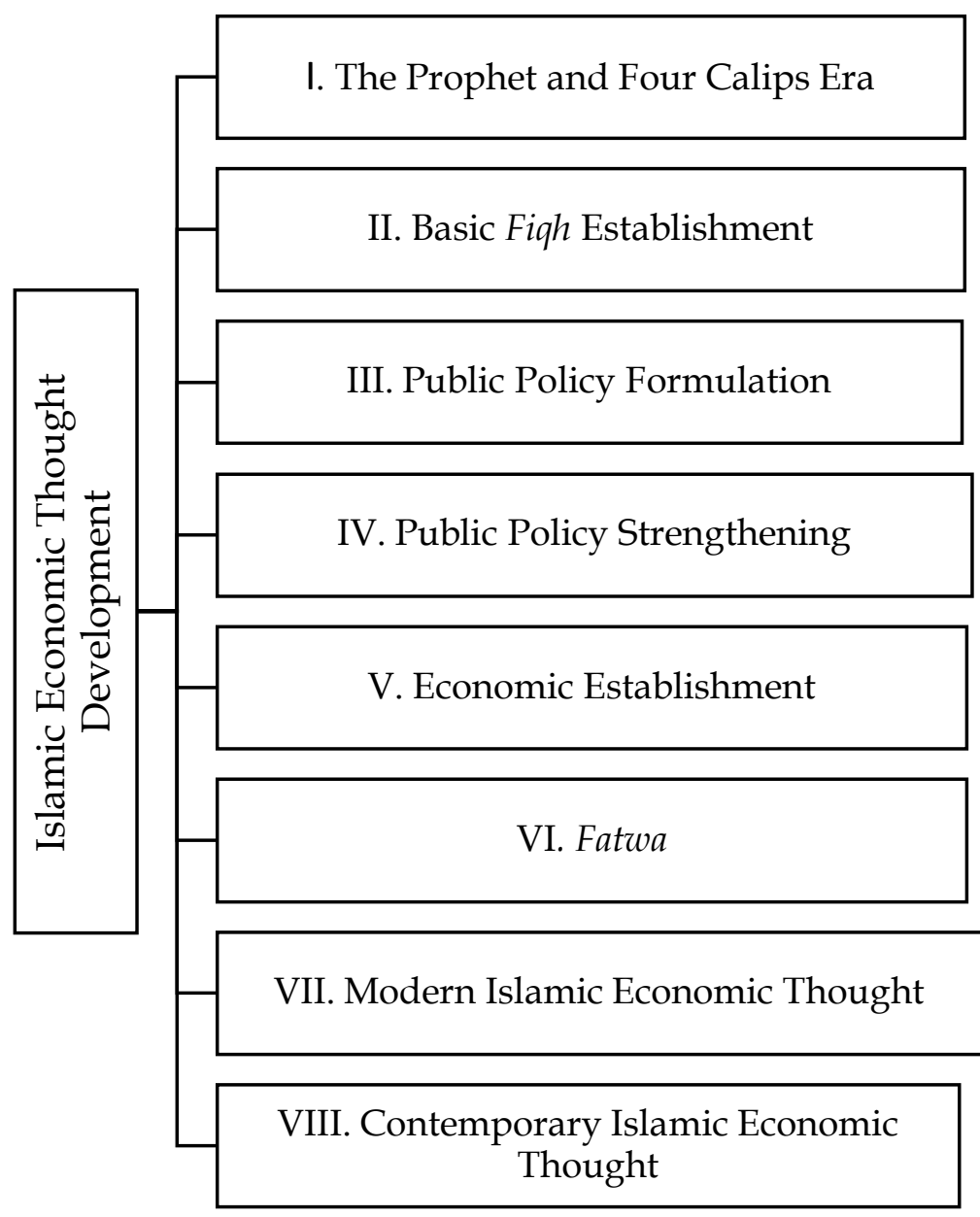

Figure 1. Islamic Economic Thought Development

Later on, the foregoing thoughts above were detailed by Ulum (2008) by apprehending the features and characteristics of Islamic economics thought observed from the social, political, and state conditions in the historical expansion of Islam from the time of Prophet Muhammad's life to this contemporary period. The characteristics are 
as follows. First, the initial period was during the time of the Prophet and the four caliphs. During this period, all legal provisions were in the power of the Prophet. This period was also marked by the establishment of foundations in order to resolve social, political, and economic circumstances. However, after the Prophet passed away and the four caliphs led until the reign of the Umawiyah era, legal issues related to social, political, and economic in Islamic society increased to more complex legal issues. In acknowledging these matters, during the reign of Umar bin Khattab (A.H 13A.D 634), ijtihad had become an extensive means of deciphering various legal issues that arose in the community. In this period, for the first time, the figh experts clashed with culture, morals, ethics, and human values in a complex society. In this era, bayt mal was formed which were the forerunners of state financial and asset managers from an Islamic perspective.

Second, it is basic figh establishment as a response to individual issues that were rife in society. From an economic perspective, this phase was the initial stage of fiqih iqtishad. The economic character and thought at this time was more about maslahah and mafsadat that are normative with the production perspective, and more microeconomic. This period occurred during the reign of the Bani Umawiyah. The wellknown Islamic scholars include Zaid bin Ali, Imam Abu Hanifah, and Anas bin Malik.

Third, public policy establishment was compiled in one book that specifically discusses economics from an Islamic perspective. Ensued at the end of Umayyad Caliphate, the distinguished figures during this period were Abu Yusuf and as-Syaibani. This period was wherein the public policy consolidation in the economy occurred. Not only compiling the books related to the economy, this era marks the leaders' efforts to strengthen public policies in regulating the country's economy that the government-owned a prominent role in the authority of economic policy. This period occurred during the early the Abbasid Caliphate. The character of Islamic economic thought in this phase emphasized the management of the state budget. The well-known 
Islamic scholars include Abu Ubaid, Yahta bin Umair, and AlMawardi.

Fourth, the era was public policy strengthening. Islamic countries experienced progress and welfare. The Muslim intellectuals remarking the sovereign who were complacent about this affluence, many of them did not pay attention to ethics. Therefore, the focus of economic thought at this era was on the issue of micro or macroeconomic ethics from an Islamic perspective. This era also marked the theories related to consumer behavior, the theory of price, the concept of money, the concept of savings, market evolution, taxes, and international trade that are also the talk of intellectuals today. This period occurred at the early of the Abbasid Caliphate. Several of the well-known Islamic scholars include Abu Hamid al-Ghazali, As-Syatibi, Ibnu Khaldun, and Al-Magrizi.

Fifth, Islamic economic thought did not thrive, only in the forms of fatwa referring to the standpoints of the madhab scholars. This phase occurred during the Ottoman empire, the well-known Islamic scholars is Syah Waliyullah. Sixth, the modern Islamic economics thought where Islamic thought was heavily influenced by Western thought, including Islamic economics. This period occurred in the period from the end of the Ottoman empire to the end of the second world war. However, there are also Muslim intellectuals who discussed Islamic economics such as Muhammad Iqbal and Muhammad Abduh.

Seventh, the contemporary Islamic economics thought when the Islamic economic revival began to flourish again. Among the wellknown Islamic scholars are Muhammad Abdul Manan, Baqr Sadr, Umar Chapra, Monze Kahf, etc. During this period, there was a debate about the concept of Islamic economics, whether it originated from Islam or was it just a label. However, they also initiated other concepts related to Islamic economics.

From the foregoing depictions of Islamic economic thought development from time to time, it is concluded that the characteristics and patterns of thought depend on the social, political, and cultural 
conditions that occur in the Muslim countries including Indonesia. Thus, it is not surprising that in Indonesia many writings are discussing the issue of zakah empowerment and Halal products as these topics became the trending discussion in this decade. This theoretical framework becomes the author's reference in analyzing the Islamic economic thought of Indonesian Muslim intellectuals.

\section{Research Method}

The present study is a library research. It seeks, analyzes, and makes interpretations of the thoughts and ideas written by several academicians of the State Islamic Religious College (PTKIN) in several scientific journals indexed in Sinta 1, Scopus, and Web of Science. Content analysis was utilized that focuses on the actual content and internal media features. In this present study, the objects of research are words, concepts, themes, sentences in the text, and the ideas contained in the text. Meanwhile, the text is defined by the text contained in books, essays, book chapters, interviews, news headlines, news articles, and documents such as history, speeches, conversations, and advertisements. The analytical content according to Weber as quoted by Satori and Komariah (2012) that is an approach of a set of procedures for drawing correct inferences from a book and document. Furthermore, Satori and Komariah (2012) illustrate this approach by excerpting Holsti's notion which states that content analysis is a technique used to draw conclusions through an effort to uncover message characteristics and is carried out objectively and systematically.

The objects of this study are articles written by PTKIN academicians that are indexed by Sinta 1, Scopus, or Web of Science. The journals included in this study were Al-Jamiah: Journal of Islamic Studies published by UIN Sunan Kalijaga Jogjakarta, Studia Islamika published by UIN Syarif Hidayatullah Jakarta, Indonesian Journal of Islam and Muslim Societies (IJIMS) published by IAIN Salatiga, Qudus International Journal of Islamic Studies (QIJIS) published by IAIN 
Kudus, and Journal of Indonesian Islam (JII) published by UIN Sunan Ampel Surabaya. Subsequently, the author only derives themes related to Islamic economic thoughts from 2013 to 2020.

\section{Results}

This section highlights the results of content analysis of a number of articles published in the above-mentioned reputable journals in Islamic studies. Several themes are clearly mentioned to indicate the priority of track record of Islamic economic development in Indonesia expressed by contemporary Muslim intellectuals.

\section{Zakah and Islamic Philanthropy}

There are several articles related to zakah and Islamic philanthropy. First, Jahar's (2015) writing entitled "Marketing Islam through Zakah Institutions in Indonesia" was published by the Studia Islamika of UIN Syarif Hidayatullah. The article revealed the idea that the starting point of Islamic social movements in Indonesia including zakah institutions cannot be identified with Islamization or politicization of Islam. For instance is Dompet Duafa zakah institution. This institution is engaged in the framework of economic, social, and community empowerment, as well as equal distribution of economic justice for the poor (duafa). It is described that the establishment of zakah institutions has nothing to do with Islamization, but rather the marketing of Islam through the sense of social justice and professionalism. This concept was established since there were statements from several Islamic intellectuals that zakah institution was the form of Islamization and politicization of Islam. However, this statement was refuted by Jahar (2015) by stating that the establishment of zakah institutions, either the Amil Zakah National Agency (Baznas) managed by the government or the Amil Zakah Institution (LAZ) managed by the private sector, do not initiate Islamization, but rather more of an attempt to oversee public affairs, including zakah funds, in state administration. This form of regulation should not automatically 
be seen as a form of Islamization. In other words, it is the state's responsibility to ensure that the funds are regularly collected and distributed from the legal organization. The zakah institution advertisements on television or social media are efforts to raise awareness of the benefits of zakah. Subsequently, marketing was utilized to comply with community needs to generate more income. Without this strategy, it is impossible for zakah agencies to gain support from the community (Jahar, 2015). Thus, the establishment of non-governmental zakah institutions is not always synonymous with Islamization or Islamic politics, but all of them aim to empower and escalate the economic level of the duafa and the indigent.

Second, Baidhawy's (2015) writing entitled "Lazismu and Remaking the Muhammadiyah's New Way of Philanthropy" Published in Al-Jāmi' ah: Journal of Islamic Studies focuses on the role of the zakah, infaq, and sadaqah institutions of Muhammadiyah organization or Muhammadiyah Philanthropic Board (Lazismu) that adapted to new philanthropic designs. This model corresponds to zakah empowerment management in order to elevate the economic level of the poor and the dhuafa. It is revealed that there were three breakthroughs made by Lazismu for empowering. The first is the supervision of zakah, infaq and shadaqah, which are funded by several philanthropists for productive and redistributive activities aimed at realizing justice and equity. Second, Lazismu is capable of running programs that exceed the expectation of muzakki (alms payer), benefactor, and donors. This is manifested in the programs extending from education development, agriculture development, youth entrepreneurship, and women empowerment, to Masjid based community empowerment. Third, in order to attract people's interest in increasing muzakki and donors, the theology was initiated by the founder of Muhammadiyah, KH. Ahmad Dahlan, to manifest transformative philanthropy that has succeeded in changing policies. In addition, there are creative and innovative programs that escalate the interest of donors and muzakki (Baidhawy, 2015). The illustration 
that can be inferred from Islamic economic thought that corresponds with zakah and Islamic philanthropy is related to the development of zakah that has been carried out by Lazismu which is considered successful and shall be used as a role model for other zakah institutions.

Third, Saidurrahman's (2013) writing entitled "The Politics of Zakah Management in Indonesia: The Tension between BAZ and LAZ" published by the Journal of Indonesia Islam concerns on the new Act of zakah management No. 23 Year 2011 that has changed the position of private zakah management. It has altered the position of zakah management of LAZ which has no relevance with governmental institutions. This law is a substitute for the Act of Zakah Management No. 38 year 1999. The findings disclosed by the author (Saidurrahmnan, 2013) that many debates on the position of private zakah management should be under the coordination of semigovernmental zakah management. Saidurrahman (2013) further argues that zakah institutions in Indonesia need to be managed properly without sacrificing social capital, such as private participation in zakah management. Subsequently, private institutions also need to be given more space in optimizing, collecting, and distributing zakah funds in Indonesia. The matter that must be addressed in managing zakah is building a regulatory agency for zakah management in Indonesia (Saidurrahmnan, 2013). Thus, there is a need to establish an exclusive agency to manage zakah in Indonesia.

Fourth, Djatmiko's (2019) writing entitled "Re-formulation Zakah System as Tax Reduction in Indonesia" was published by the Indonesian Journal of Islam and Muslim Societies (IJIMS). In his writing, Djatmiko (2019) reformulates zakah as a tax reduction. This policy can only be carried out by the government if the government has altered from "zakah as a taxable income reduction" into "zakah as a tax deduction". Thus, this transformation will increase the number of taxpayers (on one side) and also the number the mandatory amount of zakah (on the other side). Therefore, if the government to promote an 
Islamic economy by improving the management of zakah, then zakah shall be placed as a deduction from income tax. If zakah is placed as a deduction from income tax, there will be a greater impact on the larger economy, compared to when zakah is only positioned as a deduction from earnings tax (Djatmiko, 2019). There are several policy recommendations proposed in the paper (Djatmiko, 2019). First, the government shall encourage citizens to have a tax number to process zakah claims as a tax deduction. Second, tax regulations shall be adjusted so that zakah can be a tax deduction. Third, the government must also intensively announce tax incentives through zakah. Fourth, education concerning the obligation of zakah is a shared responsibility of every stakeholder, including scholars and the government. A proposal to public policymakers to equate taxes and zakah in the context of enhancing the economy in Indonesia.

Fifth, the writing of Kusuma and Ryandono (2016) entitled "Zakah Index: Islamic Economics' Welfare Measurement" was published by the Indonesian Journal of Islam and Muslim Societies. It discusses the zakah index with all its derivatives that it is the fourth pillar of Islam as its central model. This index can be employed as a magnitude of the welfare of a Muslim country or a Muslim-populated country (Kusuma \& Ryandono, 2016). Since zakah intersects all Muslim dimension in life, it will be able to indicate the level of prosperity (economy), solidarity (social), spiritual (individual). There are ratios and a Zakah welfare index to be used as measurements. However, the most significant part is that zakah fulfills the requirements of the maqasid al-Shariah in this respect compared to other conventional measures. In the future, this index can be further developed with new findings that exhibit an escalation in the welfare of Muslims (Kusuma \& Ryandono, 2016). This article proposes the measurement of Zakah Index that is intended to be an Islamic Economics tool to measure not only the welfare/wellbeing of Islamic Society but also it is religious (spiritual). 
Several of the writings related to zakah basically adjust to the social, political, and cultural conditions in Indonesia, either as an input to the government to serve as public policy or related to the development of zakah institutions. Therefore, they are developed into transparent and accountable institutions in enhancing the welfare and economy of the Muslim community particularly in Indonesia.

\section{Halal Industry}

An article related to the Halal industry expansion published by the Journal of Indonesian Islam written by Sukesi and Hidayat (2019) entitled "Managing the Halal Industry and the Purchase Intention of Indonesian Muslims: The Case of Wardah Cosmetics". This paper discusses the Halal industry and its great potential to be expanded in Indonesia. Muslims possess a distinct way of life that entails them to consume Halal commodities. These items include food, pharmaceuticals, as well as cosmetics, skincare, and hair treatment. The huge potential in the Halal industry has now been supported by legal protection, which previously did not exist. This regulation obliges producers to take measures to ensure the legality of their products as indicated by a Halal certificate issued by MUI (Indonesian Ulema Council). Not only that Halal commodities can offer beneficial legal status to Muslim consumers, but it can also offer to adherents of all religions. The logic that they build is that the purity and quality of Halal commodities are automatically guaranteed. Consumers, based on research, are crucial and shall be prioritized in every consideration of decisions made in the industry (Sukesi \& Hidayat, 2019).

Sukesi and Hidayat (2019) in her study took Wardah products as an example. These items have a good potential market. Realizing that consumers are assets, they need to prioritize them in their decisions, then initiated Halal cosmetics in Indonesia and have managed in instilling an image among Indonesian Muslim women that Halal cosmetics are Wardah. Wardah proudly shows the Halal certificates issued by MUI in all cosmetic products. Despite the understanding of 
the importance of Halal status among markets in Indonesia, Wardah also still offers high quality and attractive innovations as product advantages so that customers will appreciate their products as Halal cosmetics that are of high quality and innovative. This brand offers three principles: pure and safe, the expert in beauty, and inspiring beauty. Despite Wardah has not thrived in penetrating the rural area market, it undeniably becomes one of the leading brands in Halal cosmetics in Indonesia. This is indubitably a major accomplishment.

There is indeed a close correlation between the Halal status of a product and customer purchase intentions. This is why Wardah is relatively prompt in positioning itself among consumers. The survey denotes that Wardah has completed its mission to be recognized as Halal, highly qualified, and innovative. Wardah has taken various measures in attaining that range from the manufacturing process to the forefront of sales including ambassadors and beauty consultants. In a nutshell, Wardah is good at showcasing that the Halal industry has immense potential in Indonesia and since then Indonesian Muslim consumers value the Halal industry. The purchase intention of the Muslim market is indeed influenced by this factor, which is prevailing in agreement (Sukesi \& Hidayat, 2019). This economic thinking illustrates the immense potential for the development of the Halal industry in Indonesia. This adapts to the social and cultural aspects of the Muslim community in Indonesia.

\section{Sharia Finance}

An article related to the Islamic finance concept was delivered by Laldin and Furqani (2016) with the title "Innovation Versus Replication: Some Notes on the Approaches in Defining Sharia Compliance in Islamic Finance" published by Al-Jami'ah: Journal of Islamic Studies. The writing traces Islamic finance, becoming a new perspective in understanding finance and alternatives to the capitalist financial system. It is expected to offer something new in financial affairs. The expectation is not only in offering sharia-compliant 
financial commodities using conventional structures but also in the ability to provide different product finance that conforms to Islamic teachings. Innovations in sharia finance should be carried out to promote products and services that will provide benefits to society and economic development. Islamic finance, considered by many, has the potential to offer solutions and become a solid financial system if industry participants are willing and endeavoring to yield new approaches and frameworks in promoting Islamic finance that can be 'alternative' and not 'replicated' to conventional finance. Innovations in Islamic finance, at a later stage, will, therefore, be directed to the challenges of time.

However, to achieve all of this, it is necessary to invent a safer environment in which financial innovation is not only welcomed but also supported so that it continues to grow. It includes strong human capital, laws, and regulations that support the framework and committed participants in Islamic finance companies. Therefore, the dialogue is continuously carried out among stakeholders - the business financial sector, regulators, industrial agencies academics, consumers, and non-financial institutions (Laldin \& Furqani, 2016). The article reviews the importance of Islamic finance as an alternative to the crisis encountered by the conventional financial system.

\section{Sharia Capital Market}

An article related to the Sharia capital market is entitled "Higher Objectives of Islamic Investment Product: Islamizing Indonesian Capital Market" written by Soemitra (2016) which was published in the journal of Studia Islamika. The focus of this paper is the emergence of Islamic investment products in Indonesia. The capital market opens up opportunities for Indonesian Muslims to invest in accordance with Islamic law. A research conducted by Andri (in Soemitra, 2016) has indicated that the majority of respondents have positive responses that the Islamic capital market products in the Indonesian capital market do not only adheres with the formal regulations of Islamic law both in 
substantive aspects and procedural aspects, but also with greater goals of Islamic investment products, namely investor education, justice upholding, and social benefits manifestation. However, policymakers still have to take investor confidence to a higher level. The confidence level of middle-level investors is already a good signal for further expansion of Islamic investment products in the Indonesian capital market.

Islamic capital market regulators shall maintain and escalate investor confidence on the right track. The deeper and more thrived the products of the Islamic capital market, the more they will benefit individuals, society, and the nation. This study supports the arguments that the capital of the Islamic market is part of the Islamization agenda in the financial sector. It shall be well and broadly understood that the Islamic capital market products and other Islamic financial instruments are not only in accordance with the aspects of sharia law but must also serve as a medium for actualizing higher Islamic goals, such as socioeconomic development. The fact that modern organizations do not stay for a long time as entrepreneurial institutions, as has been expected for decades, is quite interesting. Macroeconomic factors, competition from other businesses, and internal management can be the source of this.

However, Muhammadiyah archives and more recent initiatives in the early 2000s in the field of business have pointed to another substantial challenge. It is not a simple challenge for a charity-based organization to operate an economic transformation in which the idea of divinity is central. In this process, it seems that organization can hardly be separated from what Max Weber has explained in the early $20^{\text {th }}$ century, that there is a struggle in principle between ethical rationalization and the rationalization process in the economic field. The case of Muhammadiyah indicates that Islam has historically and a vigorous commercial orientation. It could be like other religious traditions with the inherent tensions produced by overlapping religious and economic fields. This, clearly, did not prevent Muhammadiyah from being the main actor of Indonesia's religious 
and social transformation. Since the beginning of the $20^{\text {th }}$ century, it has answered the spiritual and material needs of millions of Indonesians through the needs of schools, universities, hospitals, and orphanages. At this time Indonesia is witnessing sustainable growth, a growing middle class, and a continuing religious revival; the matter of entrepreneurship is now more than ever becoming a very important issue and a matter of debate in Muhammadiyah circles (Soemitra, 2016).

\section{Discussion}

The foregoing description depicts that Indonesian scholars took careful attention to Islamic economics as reflected by their writing of Islamic economic thought. From time to time, Muslim scholars created a breakthrough in responding to advanced society. Several Muslim scholars have written on the economic and social issues of their time and provided policy advice to the rulers and guidance to the masses (Ali, 2015). However, despite numerous efforts to create one, there is no textbook of Islamic Economics showing the diversity of opinions among Muslim economists is extreme that there is no any agreement on even the definition of Islamic Economics, and no clear model of what an ideal Islamic economic system would look like in concrete and practical terms (Zaman, 2015).

The society tends to be dynamic that in Indonesia, it has experienced significant changes seen in the context of the development of science and technology (Hamzah et al, 2020). The rapid recent development of Islamic economics, both as a science and as an economic system, has received many positive reviews at the global level. So that in three decades it has progressed, both in the form of academic studies in public and private universities and operational practices (Meirison, 2017). This study shows that it is undeniable that many prominent Muslim economists who live and prosper in his time contribute largely to the body of knowledge (Suryani, 2012). 
In the present study, the author aims to describe some mapping of contemporary intellectuals thought flow as the theoretical basis in the discussion of this article. The results of this study indicate that the flow of intellectual thought of Indonesian Muslims is nearly the same as the economic thought of Al-Mawardi and Abu Ubaid at the time termed by Ulum (2008). The formulation of public policies, related to the economy is formalized and compiled in one book that specifically discusses economics from the Islamic perspective. The only difference between intellectuals in the advancement of the Islamic civilization era and contemporary intellectuals is that they are located in the publication of their thoughts. In the times of al-Mawardi and $\mathrm{Abu}$ Ubaid, they were published in the form of books, whereas contemporary intellectuals' thoughts were published in journals with an international reputation.

Muhammadiyah and Nahdhatul Ulama (NU) as the two biggest Islamic organization in Indonesia are the examples of institutions that produce movements to economic rules from religious perspectives. The campaign by Islamic economy movement pioneers to islamize the economic system and their criticisms towards the existing economic practices such as interest-based banking sparked a controversy in the society (Choiruzzad \& Nugroho, 2013). On one hand, according the concept of Kahrudin Yunus, Islamic economics must be built on the benefits of economic politics in order to construct a democratic system (Addiarrahman, 2018).

Despite the formulation of Islamic economics met debate, Islamic teachings are in conformity with the realities of human existence (Riwajanti, 2019; Zaman, 2015). The spread of Islamic finance to Indonesia was inevitably shaped by political influence (Rusyana, 2014). Islamic economy though is decided with ijtihad and personal knowledge and imaginary dialogue through experts' writing (Djakfar, 2016). Excavation from local Muslim leaders is a necessity to be done in the context of developing Islamic economic thought (Hamzah, et al., 2020). The characteristics and patterns of thought among Muslim 
intellectuals in the field of Islamic economics across history are the same, adjusting to the social, political, and cultural conditions that have occurred in several countries where these intellectuals have settled as citizens. Many scholars also have paid attention to public finance to meet the challenges they face in different times and societies (Atmaja et al., 2019). For instance, the writings of Jahar (2015), Saidurahman (2013), and Baidawy (2015) focus a lot on the issue of zakah although sometimes not all of them provide input to policymakers, which is the government. In Islamic economics, there is a social function through a variety of activities such as zakah, waqaf, and infaq, which is inherently a part of the implementation of worship to Allah SWT (Suryani, 2012).

The study of Islamic economics cannot be denied as a study that had long been developing (Suryani, 2012). Apart from the advantages in this paper, there are also many shortcomings of writing that were born from the thoughts of economists. Some of them are only used as references for scholars, while the materials related to public policy are ignored by policymakers, so that PTKIN as a center for Islamic Economic studies is ignored, even though the idea or concept about Islamic economics were born from the thoughts of lecturers at PTKIN. The importance of economic supports as part of social solidarity is denoted (Atmaja et al., 2019) to solve the problem that requires synergy from all parties (Iskandar et al., 2020).

In line with this, the government support of Islamic economic development can be seen from the Indonesia Master plan of Sharia Economics 2019-2024 issued by Indonesia Ministry of National Development Planning emphasizing Halal Food and Beverage Cluster, Halal Tourism Cluster, Islamic Capital Market, Zakah, and Waqf. The roles of government, community, political, and economic institutions are really expected to be the main focus on developing a new current of wisdom-based economic system in Indonesia (Iskandar, 2018). Naturally, the Islamic economic thought of PTKIN academics is only in the form of discourse scattered in academic journals, not a policy. 


\section{Conclusion}

This research uncovers the development of Islamic economic thought from scholars in Indonesia to indicate their map of thoughts that is based on the social, political, and cultural conditions. The spotlight themes are the issue of zakah whether it is related to zakah recipient institutions or government policies in zakah empowerment. Meanwhile, other themes are not much in the spotlight, for instance in Islamic finance or the Halal industry, sharia finance or other themes related to Islamic economics are not widely discussed by PTKIN academics. All in all, the Islamic economy thoughts have contributed to the zakah empowerment practices in Indonesia. Although this study discloses several interesting results, the data in the form of Indonesian intellectuals' thoughts about Islamic economics are limited in the Indonesian journals published by PTKIN. Therefore, future research can enhance the scope of data sources by studying Islamic economics ideas obtained from books, international journals, etc. Moreover, future studies can also shed some light on the comparison between the thoughts of Islamic economics from Indonesian intellectuals and scholars from other countries.

\section{References}

Adibuddin, A., Setiawan, D., \& Sutopo, B. (2019). The Recent Development of Islamic Economic Studies in Indonesia. Shirkah: Journal of Economics and Business, 4(1), 133-174. doi.org/10.22515/shirkah.v4i1.263

Addiarrahman. (2018). Ekonomi Kemakmuran Bersama: Indonesian Islamic Economic Thought of Kahrudin Yunus. Shirkah: Journal of Economics and Business, 3(3), 283-306. doi.org/10.22515/shirkah.v3i3.220.

Ali, S. S. (2015). Islamic economics and social justice essays on theory and policy. In H. A. El-Karanshawy et al. (Eds.), Islamic economic: Theory, policy and social justice. Doha, Qatar: Bloomsbury Qatar Foundation

Atmaja, F.F., Asmuni,_Andriansyah, Y. (2019). An Islamic Economic Perspective of Public Finance in Indonesia based on Ad- 
Dawudi's Thought in Kitab Al-Amwal. International Journal Of Scientific \& Technology Research, 8(6), 276-279

Baidhawy, Z. (2015). Lazismu and remaking the Muhammadiyah's new way of philanthropy. Al-Jami'ah: Journal of Islamic Studies, 53(2), 387-412. https:/ / doi.org/10.14421/ajis.2015.532.387-412

Chapara, M. U. (1997). Islam dan Pembangunan Ekonomi: Suatu strategi untuk pembangunan yang adil dan stabil. The International Institute Of Islamic Thought dan Thinker's Library Sdn. Bhd.

Choiruzzad, S. A. B. \& Nugroh, B. E. (2013). Indonesia's Islamic economy project and the Islamic scholars. Procedia Environmental Sciences 17, 957 - 966.

Djakfar, M. (2016). Contemporary Islamic Economic Thinking: A Sharia-based work culture reconstruction. KARSA: Jurnal Sosial dan Budaya Keislaman, 24(2), 269-281. DOI: 10.19105/karsa.v24i2.1127

Djatmiko, H. (2019). Re-formulation zakah system as tax reduction in Indonesia. Indonesian Journal of Islam and Muslim Societies, 9(1), 135-162. https:/ / doi.org/10.18326/ijims.v9i1.135-162

Hamzah, H., Yudiawan, A., Umrah, S., \& Hasbullah, H. (2020). Islamic economic development in Indonesian Islamic higher education. International Journal of Evaluation and Research in Education (IJERE), 9(1), 77-82.

Indriati, I., \& Nugroho, M. (2019). Kuznet's Hypothesis and Ibn Khaldun's Socio-Economic Dimensions. Shirkah: Journal of Economics and Business, 4(1), 49-74. doi.org/10.22515/shirkah.v4i1.266

Iskandar, A., Possumah, B.T., Arifuddin, A. (2020). Rethinking islamic economic and finance practices in indonesia: Some critical reviews. International Journal of Islamic Business and Economics, 4(2), 81-94. doi.org/10.28918/ijibec.v4i2.2751.

Iskandar. (2018). Islamic Economics as A New Current of Economic Development in Indonesia. Muqtasid: Jurnal Ekonomi dan Perbankan Syariah, 9(2), 150-158. 
Jahar, A. S. (2015). Transformasi Gerakan Ekonomi Islam Kontemporer. MIQOT: Jurnal Ilmu-Ilmu Keislaman, 39(2), 319-340. https://doi.org/10.30821/miqot.v39i2.28

Jahar, A. S. (2015). Marketing Islam through Zakah Institutions in Indonesia. Studia Islamika: Indonesian Journal For Islamic Studies, 22(3), 405-442. https:/ / doi.org/10.15408/sdi.v22i3.2353

Kusuma, K. A. (2016). Zakah index: Islamic economics' welfare measurement. Indonesian Journal of Islam and Muslim Societies, 6(2), 273-301. https:/ / doi.org/10.18326/ijims.v6i2.273-301

Laldin, M. A., \& Furqani, H. (2016). Innovation versus Replication: Some Notes on the Approaches in Defining Sharia Compliance in Islamic Finance. Al-Jami'ah: Journal of Islamic Studies, 54(2), 249272. https:/ / doi.org/10.14421/ajis.2016.542.249-272

Mannan, M. . (1970). Islamic Economics: Theory and Practice. Lahore: Sh. Muhammad Ashraf.

Meirison. (2017). The development of Islamic economics in various parts of the world. JEBI (Jurnal Ekonomi dan Bisnis Islam), 2(2), 197206.

Rahardjo, M. D. (1985). Sistem Ekonomi Alternatif. Dalam "Sepercik Pemikiran tentang Ekonomi Islam". M. N. Arsyad: Ananda.

Riwajanti, N. I. \& Fadloli. (2019). Mosque-Based Islamic Cooperative for Community Economic Development . Review of Integrative Business and Economics Research, (8),2, 196-208.

Rusyana. (2014). Islam and Economic Development: Exploring the Role of Indonesian Muslim Society in Developing Islamic Microfinance Institution. International Journal of Nusantara Islam, 2(1), 83-94.

Siddiqi, M. N. (1986). Pemikiran ekonomi Islam: suatu penelitian kepustakaan masa kini (1st ed.). Lembaga Islam untuk Penelitian dan Pengembangan Masyarakat (LIPPM). https://doi.org/0211292633.

Saidurrahmnan. (2013). The politics of zakah management in Indonesia: The tension between BAZ and LAZ Saidurrahman. 
Journal of Indonesian Islam, 7(2), 366-382.

Satori, D., \& Komariah, A. (2015). Model of Management Capacity Building for Improving the Quality of School. Journal of Education and Learning, 9(4), 328-333.

Soemitra, A. (2016). Higher Objectives of Islamic Investment Product: Islamizing Indoensian Capital Market. Studia Islamika, 23(2), 237269.

Sudiarti, S., Harahap, P., Safarida, N. (2017). Mawah \& Cater di Aceh: Studi Peningkatan Kesejahteraan masyarakat di Ulim Kab. Pidie Jaya. Al-Muamalat: Jurnal Hukum \& Ekonomi Syariah. 3(1), 135-153.

Sukesi \& Hidayat, W. G. P. A. (2019). Managing the Halal Industry and The Purchase Intention Of Indonesian Muslims: The Case of Wardah Cosmetics. Journal of Indonesian Islam, 13(1), 200-229. DOI: 10.15642/JIIS.2019.13.1.

Suryani. (2012). The significance of islamic economics study in discipline of modern economics. Journal of Indonesian Economy and Business, 27(1), 111-121.

Syahbudi. (2003). Pemikiran Dan Gerakan Sistem Ekonomi Islam di Indonesia. Hermeneia: Jurnal Kajian Islam Interdisipliner, 2(2), 196216.

Ulum, F. (2008). Sejarah Pemikiran Ekonomi Islam. Surabaya: Fakultas Syariah dan Hukum UIN Sunan Ampel.

Zaman, A. (2015). Crisis in Islamic economics: Diagnosis and prescriptions. In H. A. El-Karanshawy et al. (Eds.), Islamic economic: Theory, policy and social justice. Doha, Qatar: Bloomsbury Qatar Foundation. 